\title{
Gene expression, oxidative stress and apoptotic changes in rabbit ileum experimentally infected with Eimeria intestinalis
} \author{
Saleh Al-Quraishy ${ }^{3}$ and Abdel-Azeem S. Abdel-Baki ${ }^{1,3}$ \\ ${ }^{1}$ Zoology Department, Faculty of Science, Beni-Suef University, Beni-Suef, Egypt; \\ ${ }^{2}$ Parasitology Department, Faculty of Veterinary Medicine, Beni-Suef University, Beni-Suef, Egypt; \\ ${ }^{3}$ Zoology Department, College of Science, King Saud University, Riyadh, Saudi Arabia
}

Heba M. Abdel-Haleem ${ }^{1}$, Shawky M. Aboelhadid ${ }^{2}$, Thabet Sakran ${ }^{1}$, Gamal El-Shahawy $^{1}$, Huda El-Fayoumi ${ }^{1}$,

\begin{abstract}
Coccidiosis is a parasitic disease caused by protists (apicomplexans) of the genus Eimeria Schneider, 1875 and is considered to be the most important disease faced by rabbit breeders due to its high morbidity. In the present study, the antioxidant status and changes in apoptosis and in the expression of some genes were quantified in rabbits' ilea following infection with Eimeria intestinalis Cheissin, 1948. Rabbits, orally infected with $1 \times 10^{5}$ sporulated oocysts of E. intestinalis, started to shed oocysts in their faeces on 8 days post infection (dpi) and reached maximum excretion on $10 \mathrm{dpi}$, with approximately 5 million oocysts. This was accompanied by a significant decrease in the live body weight of infected rabbits. Also, malondialdehyde and nitric oxide were significantly increased while catalase and glutathione were significantly decreased in the ileum tissues of the infected rabbits. In addition, a significant increase was observed in the percentages of apoptotic cells in the ilea of the infected rabbits. Furthermore, interleukin- $1 \beta$ and interleukin-2 mRNA levels were significantly down-regulated and mRNA levels of interleukin-6, interferon gamma and inducible nitric oxide synthase were significantly up-regulated, while those of C-reactive protein remained unchanged. We conclude that infection with E. intestinalis induces oxidative stress, a significant increase in the percentage of apoptotic cells and a diverse and robust Th1 and Th1-related cytokine response in the ileum tissues.
\end{abstract}

Keywords: Coccidia, malondialdehyde, catalase, intestine, Real time PCR, apoptosis

Coccidiosis is a disease caused by obligate protistan intracellular parasites belonging to the genus Eimeria Schneider, 1875 and is considered to be the most important disease faced by rabbit breeders, because of its high morbidity (Oncel et al. 2011). So far, 15 species of Eimeria have been identified as infecting rabbits; 14 of these are parasites of the intestine whereas one exclusively invades the liver and the bile duct ( $\mathrm{Li}$ and Ooi 2009). In Egypt, rabbit meat is a valuable source of animal protein and thus a survey was carried to determine the natural prevalence of infection with Eimeria spp. among domestic rabbits in Egyptian domestic farms (Balicka-Ramisz et al. 2014). El-Shahawi et al. (2012) detected eight species of Eimeria , with the overall prevalence reaching $70 \%$ and the predominant species being E. intestinalis Cheissin, 1948 and E. coecicola Cheissin, 1947.

Out of the 15 Eimeria species infecting rabbits in different parts of the world (Li and Ooi 2009), E. intestinalis has been recognised as one of the most pathogenic and highly immunogenic species (Pakandl et al. 2008). Vadlejch et al. (2010) confirmed that $E$. intestinalis is lethal for rabbits and causes a high mortality rate. Sporozoites of E. intestinalis first in- vade the mucosa of the duodenum of the rabbits, with further development occurring in the jejunum and ileum (Pakandl et al. 2006). The structural changes associated with the endogenous development has been previously investigated (Pakandl 2009), but gene expression, antioxidant status and apoptotic changes in the host target sites in response to infection with E. intestinalis have not yet been investigated. Accordingly, the main aim of the present study was to profile the antioxidant status and changes in apoptosis and in the expression of some genes following infection with $E$. intestinalis.

\section{MATERIALS AND METHODS}

\section{Animals and infection}

The animals used in the present study were sourced from the animal facilities of the Faculty of Science, Beni-Suef University, and were eight weeks old female rabbits of the New Zealand race (Oryctolagus cuniculus Linnaeus) and a mean weight of $1.5 \mathrm{~kg}$ $\pm 0.25 \mathrm{~kg}$. Rabbits were housed individually in plastic cages and kept under constant conditions for one week before use. The faeces of these rabbits were examined daily during this week to affirm the absence of any parasitic infections. 
To calculate the day of maximum oocyst output during infection with $E$. intestinalis, eight rabbits were inoculated with $100 \mu$ saline containing $1 \times 10^{5}$ sporulated purified oocysts of E. intestinalis isolated from a natural infection in Egypt using the single oocyst method (Kvičerová et al. 2008, Li and Ooi 2009). Fresh faeces were collected once every $24 \mathrm{~h}$ for 14 days from each rabbit individually. Then, oocyst output was determined using the modified McMaster technique (Schito et al. 1996) and the data were presented as the number of oocysts per gram of faeces.

\section{Experimental Design}

Rabbits were divided into two groups with eight animals per group. The first group was gavaged with saline and served as the control, uninfected, group. The second group was inoculated orally with approximately $1 \times 10^{5}$ sporulated purified oocysts of E. intestinalis in $100 \mu \mathrm{l}$ saline for each animal. On $10 \mathrm{dpi}, 16$ rabbits were euthanised with ketamine $(50 \mathrm{mg} / \mathrm{kg})$ and dissected. Ileums of non-infected and infected groups were aseptically removed. Small pieces of ileum were rapidly washed in sterile physiological saline and immediately stored at $-80^{\circ} \mathrm{C}$ for the assay of oxidant/antioxidant markers and quantitative real-time PCR. Other parts of the ileums were used fresh to detect any apoptotic changes. For histology, small pieces of ileum were fixed in $10 \%$ buffered formalin and embedded in paraffin. Then, sections were cut and stained with hematoxylin and eosin.

\section{Oxidative biomarkers}

Oxidant/antioxidant markers, including malondialdehyde (MDA), nitric oxide (NO), catalase (CAT) and glutathione (GSH), were colorimetrically assayed using chemical kits (Biodiagnostic Co., Cairo, Egypt) and the absorbance of the reactions measured by Ultrospec 2000, UV/visible Spectrophotometer (Mettler-Toledo International Inc., Columbus, Ohio, USA), as follows: levels of MDA in ileum homogenate were estimated following the method of Ohkawa et al. (1979). In an acidic medium, thiobarbituric acid reacts with malondialdehyde for $30 \mathrm{~min}$ at a temperature of $95^{\circ} \mathrm{C}$ to form thiobarbituric acid reactive species. The absorbance reading of the resultant pink product was performed at $534 \mathrm{~nm}$.

Concentration of NO in ileum homogenate was assayed according to the method of Montgomery and Dymock (1961). In the acidic medium, the present nitrite forms nitrous acid diazotising sulphanilamide that can couple with N-(1-naphthyl) ethylenediamine to form azo dye which can be measured at $540 \mathrm{~nm}$.

CAT in ileum homogenate was assayed according to Aebi (1984). Catalase is able to react with a known amount of $\mathrm{H}_{2} \mathrm{O}_{2}$ in one minute prior to stopping the reaction with a catalase inhibitor. The remaining $\mathrm{H}_{2} \mathrm{O}_{2}$ reacts with 3,5-dichloro-2-hydroxybenzene sulfonic acid and 4-aminophenazone in the presence of horseradish peroxidase to form a chromophore with a colour density inversely proportional to the quantity of catalase in the original specimen, which can be measured at $510 \mathrm{~nm}$.

GSH in ileum homogenate was measured according to Beutler et al. (1963). The method is based on the principle that reduction of 5,5'dithiobis (2-nitrobenzoic acid) with GSH will produce a yellow compound. The reduced chromogen is directly proportional to the amount of GSH and the absorbance can be measured at $405 \mathrm{~nm}$.

\section{Detection of apoptosis using propidium iodide and flow cy- tometry}

The effect of infection with $E$. intestinalis on the induction of apoptosis in the intestinal epithelia was investigated using propidium iodide (PI) staining and flow cytometry according to Hishikawa et al. (1999) and Badr et al. (2012). In brief, the method is as follows: ileum cell suspensions were prepared according to Renaux et al. (2003). Small parts of the ilea were flushed with PBS. Fat and Peyer's patches were removed and samples were opened longitudinally and cut into small pieces. The mucosal layer was scraped and then dispatched by mechanical disruption for $15 \mathrm{~min}$ in RPMI-1640 using a magnetic stirring bar.

The separated cells were washed twice in RPMI-1640 by centrifugation and filtred to remove cell aggregates and tissue debris. Cells were counted using a trypan blue exclusion test. Cells $\left(1 \times 10^{6} /\right.$ tube) were washed in phosphate buffer saline (PBS), fixed and permeabilised by incubation in $100 \mu \mathrm{l}$ of $70 \%$ ice-cold ethanol for 30 minutes on ice. After permeabilisation, $1 \mathrm{ml}$ of PBS was added to each tube, gently centrifuged $(40 \times g)$ for $5 \mathrm{~min}$ before the supernatants were aspirated. Cells were resuspended in $100 \mu \mathrm{PBS}$ and the DNA was stained by incubating the cells for $1 \mathrm{~h}$ at $4{ }^{\circ} \mathrm{C}$ in $1 \mathrm{ml}$ of PBS containing equal volumes of PI and DNase free RNase. Cells were then washed twice in PBS and fixed in $0.5 \mathrm{ml} \mathrm{PBS}+2 \%$ formaldehyde.

Stained cells were analysed by determining the FL2 red fluorescence on a linear scale. The percentage of apoptotic cells was estimated as the percentage of hypodiploid cells (sub G0/G1 peak). A four colour flow cytometry assay was carried out using standard FACSCalibur (BD Biosciences, San Jose, California, USA) and FACSDiva software (BD Biosciences). Data analysis was performed using FlowJo software, version 9 for Mac (Tree Star, Inc., Ashland, OR, USA).

\section{Quantitative Real-Time PCR}

Total RNA was isolated from frozen pieces of ileum using an animal tissue RNA purification kit (Norgen Biotek Crop., Thorold, Canada). A Nanodrop 8000 spectrophotometer (Thermo-Scientific, Wilmington, North Carolina, USA) was used to determine the concentration of the extracted RNA, while the RNA quality was detected on $1 \%$ agarose gel using a gel documentation unit (Universal Hood II, Bio Rad, Berkeley, USA).

RNA samples were converted into cDNA using a SCRIPT Reverse Transcriptase kit (Jena Bioscience GmbH, Jena, Germany) according to the manufacturer's protocol. The quantitative real-time PCR (RTPCRq) was performed by QuantiTect Eva Green PCR kit (Qiagen, Hilden, Germany) using Light Cycler (Roche, Indianapolis, Indiana, USA). The present study evaluated the some genes encoding the mRNAs for the following proteins: interleukin-1 $\beta$ (IL-1 $\beta$ ), interleukin-2 (IL-2), interleukin-6 (IL-6), inducible nitric oxide synthase (iNOS), and C-reactive protein (CRP). Primers were purchased from Qiagen.

PCRs were performed as follows: $10 \mathrm{~min}$ at $95^{\circ} \mathrm{C}$ followed by 40 cycles including denaturation at $95^{\circ} \mathrm{C}$ for $15 \mathrm{~s}$, annealing at $60^{\circ} \mathrm{C}$ for $20 \mathrm{~s}$ and elongation at $72^{\circ} \mathrm{C}$ for $20 \mathrm{~s}$. All the real-time PCR experiments were carried out in triplicate and data were presented as the mean of the results of these three independent experiments. The amplification data were quantitatively evaluated 
using Light Cycle 480 software (Roche) and the 2- $\Delta \Delta \mathrm{CT}$ method (Livak and Schmittgen 2001).

\section{Statistical analysis}

The student's $t$-test was performed to determine significant differences using Sigma Plot software version 11 (Erkrath, Rhine-Westphalia, Germany).

\section{RESULTS}

Light microscopic examination of hematoxylin and eosin-stained sections revealed that the epithelial cells of the ileum were infected with different developmental stages of Eimeria intestinalis including final oocysts enclosed in the parasitophorous vacuole (Fig. 1). All the infected rabbits shed oocysts in the course of patency. Oocyst shedding started on 8 dpi with a mean value of about $2 \times$ $10^{6}$ oocyst/g, and rose rapidly to reach a peak on $10 \mathrm{dpi}$, with mean value of about $5 \times 10^{6}$ oocyst/g. Oocyst excretion started to decline on $11 \mathrm{dpi}$ and approximately $2.2 \times$ $10^{6}$ oocysts/g were excreted on 14 dpi (Fig. 2).

It was observed that all infected rabbits exhibited signs of diarrhoea, which was most evident on 9 dpi. The live body weight of the infected rabbits $(1.30 \pm 0.2 \mathrm{~kg})$ had decreased significantly compared to the uninfected ones $(1.75 \pm 0.3 \mathrm{~kg})$ on $10 \mathrm{dpi}$.

In the ileum homogenates, infection with $E$. intestinalis induced a highly significant increase in MDA and NO, and a highly significant decrease in CAT, as well as reduced GSH (Table 1).

The results showed that, on $10 \mathrm{dpi}$, the percentage of apoptotic cells in the ileum cell suspension from the infected group was significantly higher $(31.1 \% \pm 2.2 \%)$ than in the uninfected group $(9.3 \% \pm 1.8 \%)$ (Figs. 3$)$.

The mRNA expression of the inflammatory cytokine IL-1 $\beta$ and IL-2 were significantly down-regulated while that of IL-6 and interferon gamma (IFN- $\gamma$ ) were significantly up-regulated (Fig. 4). Also, iNOS-mRNA increased significantly upon infection, which was consistent with the significant increase in the content of nitric oxide in the ileum tissue (Table 1). However, the mRNA expression of CRP was not affected by the infection.

\section{DISCUSSION}

The pattern of oocyst shedding starting on $8 \mathrm{dpi}$, reaching a peak on 10 dpi before declining increasingly rapidly from 11 dpi confirms the work of Vadlejch et al. (2010), who obtained a similar pattern with Eimeria intestinalis. The presence of diarrhoea in the experimentally infected rabbits also accords with some previous studies (Vadlejch et al. 2010, Elfayoumi and Abdel-Haleem 2014). The fact that symptoms of diarrhoea were most evident on 9 dpi is in line both with Vadlejch et al.'s (2010) work and with the contention that gametogenesis begins to develop on 8-10 dpi (El-Shahawi et al. 2012).

By ten days post infection infected rabbits exhibited significant weight loss and severe growth retardation. Drouet-Viard et al. (1997) and Metwaly et al. (2013) described a similar weight loss rabbits. The significant body weight loss in the infected rabbits was probably partly due to the

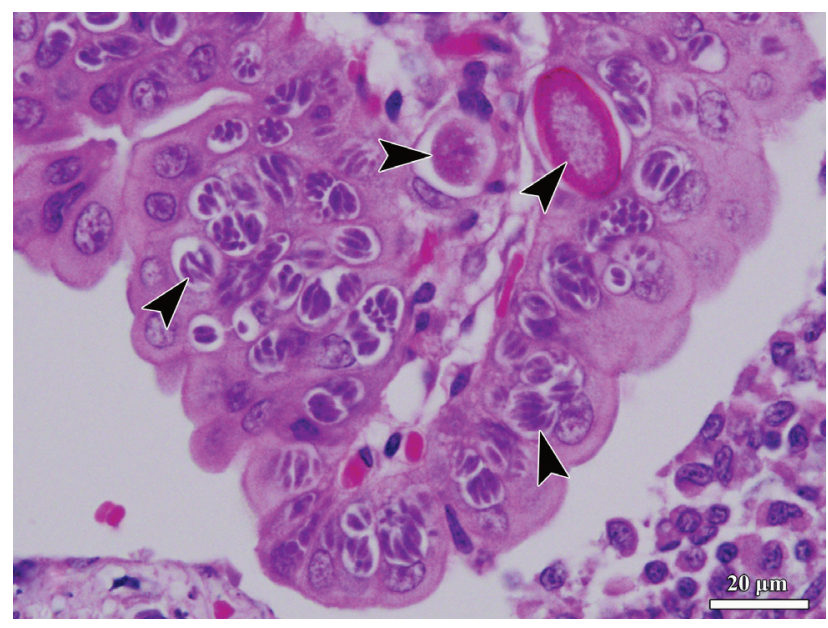

Fig. 1. Histological section of ileum infected with different developmental stages (arrowheads) of Eimeria intestinalis Cheissin, 1948 enclosed in parasitophorous vacuole.

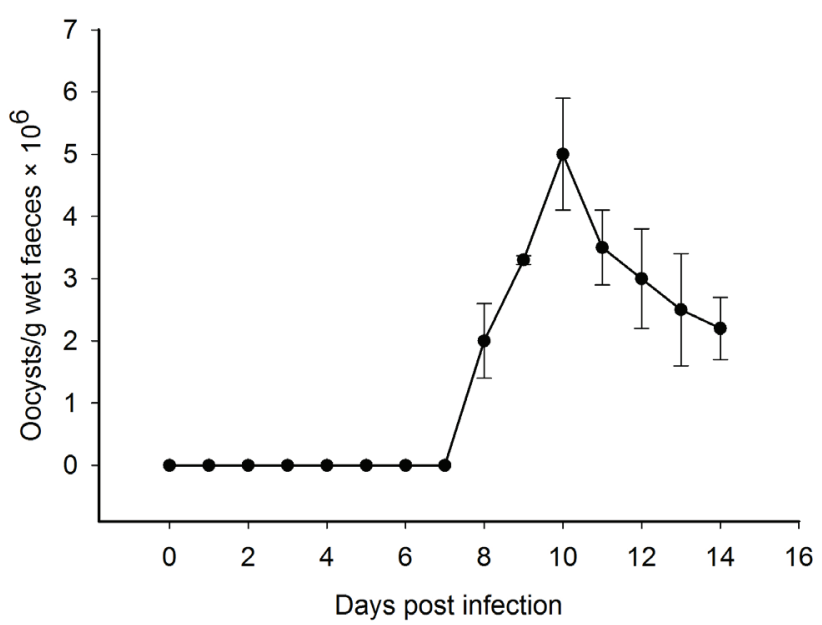

Fig. 2. Rate of shedding of oocysts of Eimeria intestinalis Cheissin, 1948 per day. All values are means \pm SD.

Table 1. Levels of oxidative stress biomarkers in ileum homogenate of rabbits infected with Eimeria intestinalis Cheissin, 1948 on 10 dpi.

\begin{tabular}{lcc}
\hline Parameter & Non-infect rabbit & Infected rabbit \\
\hline Malondialdehyde $(\mathrm{nmol} / \mathrm{g})$ & $32.3 \pm 1.1$ & $55.4 \pm 1.7^{*}$ \\
Nitric oxide $(\mu \mathrm{mol} / \mathrm{g})$ & $59.3 \pm 4.3$ & $142.7 \pm 2.6^{*}$ \\
Catalase $(\mathrm{U} / \mathrm{g})$ & $5,273 \pm 25$ & $4,247 \pm 50^{*}$ \\
Glutathione $(\mathrm{mg} / \mathrm{g})$ & $19.5 \pm 0.5$ & $14.9 \pm 0.7^{*}$ \\
\hline
\end{tabular}

Values are mean $\pm \mathrm{SD} ; *$ significant change at $\mathrm{P}<0.05$ with respect to the non-infected group.

deterioration in the food conversion rate and is doubtless also related to impaired endogenous enzymatic systemic defence (Chapman 1997, Georgieva et al. 2006). Metwaly et al. (2013) also attributed the reduction in rabbits' body weight during the course of intestinal coccidial infection to factors including depletion of growth hormones, distributed metabolic status and electrolyte homeostasis.

The results of the present study showed increased ileum tissue MDA and NO and decreased CAT and GSH con- 


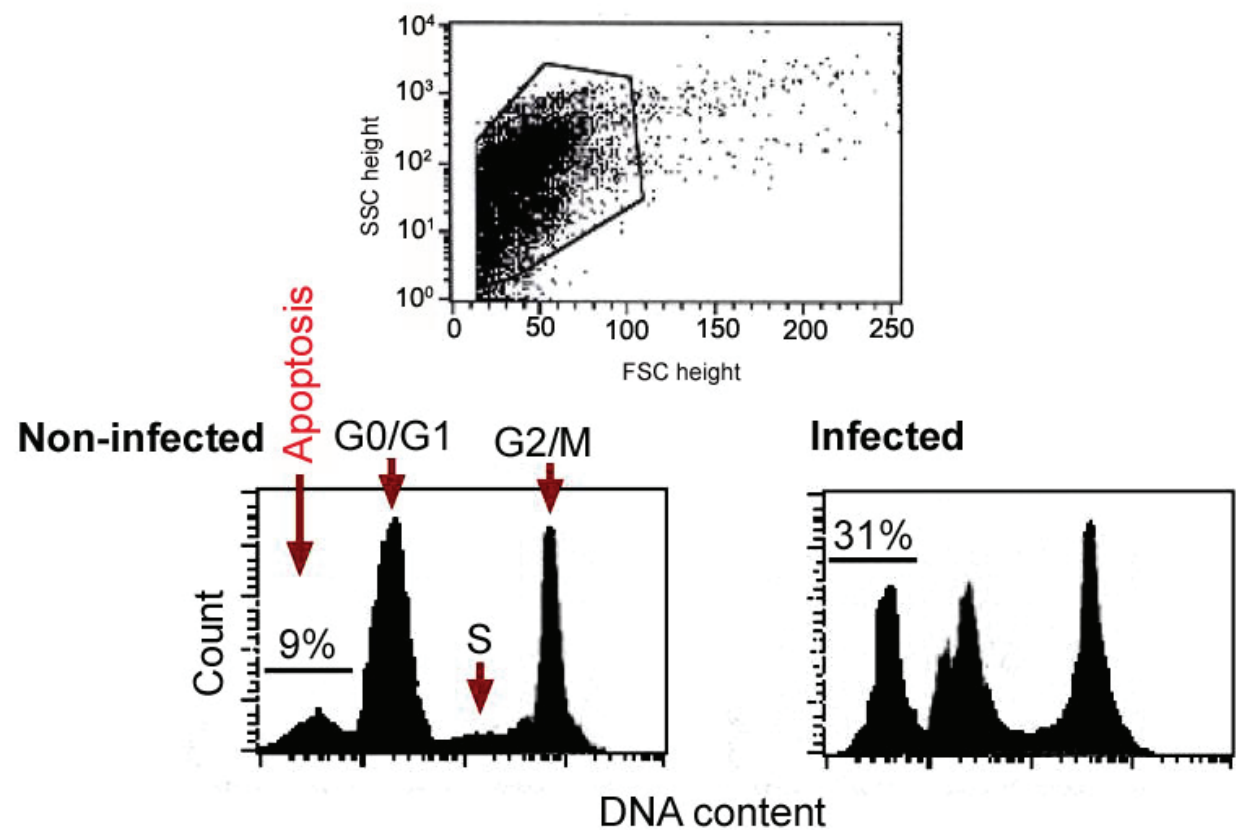

Fig. 3. One representative experiment of six rabbits for DNA florescence flow cytometric profie of PI-stained ileum cell suspension of non-infected and infected rabbits at day 10 post-infection. Abbreviations: FSC - forward-scattered light; G0-G2, M, S - representing the cell cycle phases; SSC - side-scattered light.

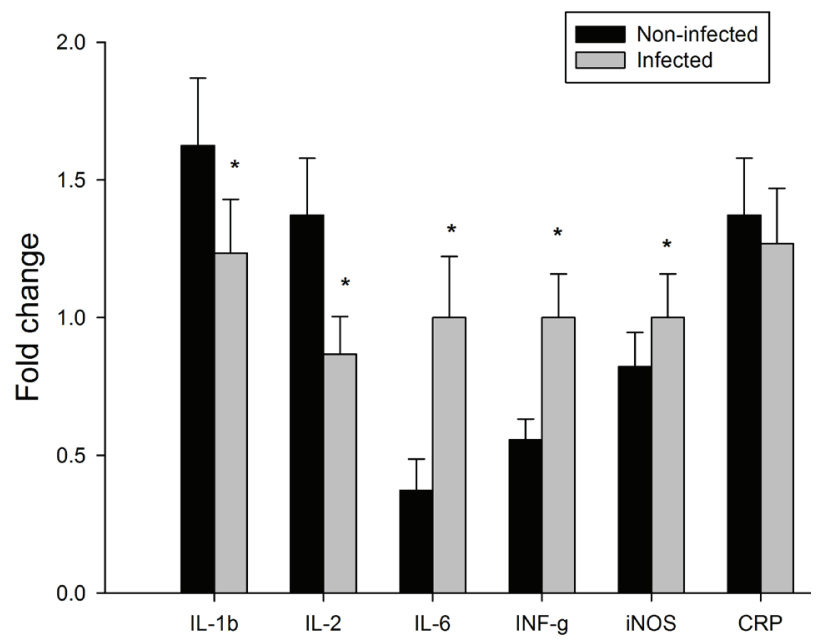

Fig. 4. Quantitative RT-PCR analysis of interleukin-1 $\beta$ (IL-1 $\beta$ ), interleukin-2 (IL-2), interleukin-6 (IL-6), interferon gamma (IFN- $\gamma$ ), inducible nitric oxide synthase (iNOS) and C-reactive protein (CRP) in the ileum. Expression was analysed in non-infected and infected rabbits on day 10 post-infection, normalised to HPRT1 signals; relative expression is given as -fold increase compared to the non-infected control rabbit. Values are means \pm SD. * Significant change at $\mathrm{p}<0.05$ with respect to non-infected rabbit.

centrations in the infected rabbits compared to controls. Similarly, Eraslan et al. (2004), Ahmed and Hassan (2007) and Dkhil et al. (2012) each noticed increased levels of MDA and NO as a result of the stressful conditions following infection with E. tenella Raillet and Lucet, 1891, Eimeria sp. and E. coecicola, respectively. The elevated MDA concentration in rabbits infected with $E$. intestinalis in our experiment could be due to increased production of reactive oxygen species, resulting from lipid peroxidation (Georgieva et al. 2006). Dkhil et al. (2012) suggested that the increased levels of MDA and NO are a result of serious inflammatory response due to oxidative damage caused by coccidian infection.

Several studies, meanwhile, have postulated that the decrease in CAT and GSH activity during the course of eimeriosis might be due to the cellular defence systems being overwhelmed by excessive formation of reactive compounds, and that this is suggestive of oxidative stress (Eraslan et al. 2004, Ahmed and Hassan 2007, Çam et al. 2008). The increases in MDA and NO and decreases in CAT and GSH observed in this study tend to support this picture of impaired antioxidant status and the occurrence of oxidative stress in rabbits infected with E. intestinalis.

Our data also showed a significant increase in the percentages of apoptotic cells in the infected ileum compared to the control one. The intracellular stages of the coccidian parasites are known to modify their host cells quite extensively and to interfere with many host signalling pathways, including induction of host cell apoptosis in order to maximise their own chances of survival (Lüder et al. 2001, 2009).

Fisch et al. (2007) and Green (2000) postulated that the parasite invasion and replication might cause considerable stress to the host cell and that this stress, in turn, may trigger apoptosis. This contention was supported by Yan et al. (2015), who observed that infection with E. tenella promoted apoptosis during the different developmental stages, especially through gamogony and sporogony. This may be due to the fact that merogony of species of Eimeria requires a stable intracellular environment to obtain essential nutrients and evade host immune attack and therefore Eimeria 
infection may directly activate the NF- $\kappa \mathrm{B}$ pathway in host cells to further inhibit host-cell apoptosis (Salminen et al. 2012).

Whereas gamogony and sporogony may prevent the expression of the NF- $\kappa$ B response gene (Yan et al. 2015) then they further decrease the expression of the anti-apoptotic proteins $\mathrm{Bcl}-2$ and $\mathrm{BclXL}$, which accelerate host-cell apoptosis (Rasul et al. 2012). Liu et al. (2009) also realised that the merogony of Cryptosporidium parvum Tyzzer, 1912 upregulated the genes with antiapoptotic roles and downregulated the genes with apoptotic roles while gamogony and sporogony downregulated the anti-apoptotic genes and induced proapoptotic gene. Therefore, they suggested a biphasic regulation of apoptosis: antiapoptotic state in the early infection and apoptotic state in the mid and late infection.

Other factors that contribute to apoptosis during the course of eimeriosis are the elevation of reactive oxygen species and the presence of nitrogen intermediates and inflammatory cytokines within the infected cells (Major et al. 2011, Metwaly et al. 2014).

Our present data suggest remarkable inflammatory responses (Th1 cytokines), indicated by significantly down-regulated levels of IL-1 $\beta$ and IL-2 mRNA (in line with Dkhil et al. 2011 and Hong et al. 2006), and significantly up-regulated levels of IL-6, IFN- $\gamma$ and iNOS. Kaiser et al. (2000) have suggested that the down-regulation of IL-1 $\beta$ and IL-2 might lead to a slower inflammatory response in the gut, thus allowing initial entry of the coccidia into epithelial cells.

In terms of the up-regulated levels of IL-6, Dkhil et al. (2012) reported significantly up-regulated mRNA expression of IL-6 in rabbit appendices infected with E. coecicola, and several authors have speculated that IL-6 plays a role in the initiation of anti-eimerian effector responses, particularly upon the generation of Th1 effector responses during primary infection (Lynagh et al. 2000, Dkhil et al. 2012). Swaggerty et al. (2004) and Hong et al. (2006) have also suggested that the increased expression of IL-6 may be to create a population of neutrophils more capable of responding to and eliminating pathogens.

IFN- $\gamma$, which is thought to activate the intracellular toxicity, is powerfully increased during infection, which suggests that it possesses a particular role in infection with species of Eimeria (Dkhil et al. 2011). The notably increased levels of IFN- $\gamma$ in the intestine during infection with E. bovis Zublin, 1928 and E. alabamensis Christensen, 1941, E. maxima Tyzzer, 1929 and E. papillata Ernst, Chobotar et Hammond, 1971 (see Alcala-Canto and Ibarra-Velarde 2008, Cornelissen et al. 2009, Dkhil et al. 2011) provide a broad-based body of evidence in support of its role during eimeriosis. Dkhil et al. (2011) suggest that IFN- $\gamma$ reduces the output of oocysts throughout primary infection with Eimeria. Additionally, IFN- $\gamma$ is considered to be a major cytokine mediating resistance to many coccidian parasites including Eimeria (see Hong et al. 2006).

MacMicking et al. (1997) postulated that IFN- $\gamma$ is a potent iNOS inducer; this would explain the concurrently high mRNA levels of IFN- $\gamma$ and iNOS observed in the intestine of rabbits infected with E. intestinalis in the present study, as has also been reported in the case of infection with E. maxima (see Hong et al. 2006). Moreover, the detrimental effect of IFN- $\gamma$ on the intracellular replication of Eimeria spp. is well documented, with NO being proposed as the effector molecule (Taubert et al. 2009). This suggests that iNOS up-regulation is coherent with the increase of nitrite/nitrate within tissue contents reported during the present study.

Many studies also proved that the increased IL- 6 gene expression enhanced NO production through increasing the induced iNOS expression (Kang et al. 2007, Maalouf et al. 2010). CRP has been suggested as a preferable biomarker for chronic and acute inflammation (Dortay et al. 2011). CRP is primarily synthesised within the liver in response to IL-6, with the synthesis being enhanced synergistically by IL-1 $\beta$ (Marnell et al. 2005). This synergistic relationship may imply that the low levels of IL- $1 \beta$ mRNA and high levels of IL- 6 mRNA found in this study may be working together to result in the unchanged CRP expression that was observed. Overall our data suggests that the infection with $E$. intestinalis induces oxidative stress, a significant increase in the percentage of apoptotic cells and a diverse and robust Th1 and Th1-related cytokine response in the ileum tissue.

Acknowledgements. We extend our appreciation to the Deanship of Scientific Research, King Saud University, Riyadh for funding the work through the research group project number RGP -004.

\section{REFERENCES}

Aeвi H. 1984: Catalase. In: H.U. Bergmeyer (Ed.), Methods of Enzymatic Analysis. Academic Press, New York, pp. 673-684.

Ahmed W.M., Hassan S.E. 2007: Applied studies on coccidiosis in growing buffalo-calves with special reference to oxidant/antioxidant status. World J. Zool. 2: 40-48.

Alcala-Canto Y., IbarRa-Velarde F. 2008: Cytokine gene expression and NF-kappa B activation following infection of intestinal epithelial cells with Eimeria bovis or Eimeria alabamensis in vitro. Parasite Immunol. 30: 175-179.

Badr G., Garraud O., Daghestani M., Al-Khalifa M.S., RichaRd Y. 2012: Human breast carcinoma cells are induced to apoptosis by samsum ant venom through an IGF-1-dependant pathway, PI3K/AKT and ERK signaling. Cell. Immunol. 273: $10-16$.
Balicka-Ramisz A., Wróbel M., Adadyńska K. 2014: Epidemiology and economic benefits of treating rabbits coccidiosis in small farms from West Pomerania province, Poland. Ann. Parasitol. 60: 247-251.

Beutler E., Duron O., Kelly B.M. 1963: Improved method for the determination of blood glutathione. J. Lab. Clin. Med. 61: 882-888.

Çam Y., Atasever A., Eraslan G., Kibar M., Atalay O., Beyaz L., İnci A., Liman B.C. 2008: Eimeria stiedae: experimental infection in rabbits and the effect of treatment with toltrazuril and ivermectin. Exp. Parasitol. 119: 164-172.

CHAPMAN H.D. 1997: Biochemical, genetic and applied aspects of drug resistance in Eimeria parasites of the fowl. Avian Pathol. 26: 221-244. 
Cornelissen J.B., Swinkels W.J., Boersma W.A., Rebel J.M. 2009: Host response to simultaneous infections with Eimeria acervulina, maxima and tenella: a cumulation of single responses. Vet. Parasitol. 162: 58-66.

Dkhil M., Abdel-Baki A.S., Delić D., Wunderlich F., Sies H., Al-Quraishy S. 2011: Eimeria papillata: upregulation of specific miRNA-species in the mouse jejunum. Exp. Parasitol. 127: 581-586.

Dкhil M.A., Abdel-Maksoud M.A., Al-Quraishy S., АвDEL-BAKI A.S., Wunderlich F. 2012: Gene expression in rabbit appendices infected with Eimeria coecicola. Vet. Parasitol. 186: $222-228$.

Dortay H., Schmöckel S.M., Fettke J., Mueller-Roeber B. 2011: Expression of human C-reactive protein in different systems and its purification from Leishmania tarentolae. Protein Expr. Purif. 78: 55-60.

Drouet-Viard F., Coudert P., Licois D., Boivin M. 1997: Vaccination against Eimeria magna coccidiosis using spray dispersion of precocious line oocysts in the nest box. Vet. Parasitol. 70: 61-66.

Elfayoumi H., Abdel-Haleem H.M. 2014: Electron microscopic study of the developmental stages of Eimeria intestinalis Cheissin, 1948 in domestic rabbit (Oryctolagus cuniculus) with reference to endodyogeny. J. Egypt. Soc. Parasitol. 44: 531-538.

El-Shahawi G.A., El-Fayomi H.M., Abdel-Haleem H.M. 2012. Coccidiosis of domestic rabbit (Oryctolagus cuniculus) in Egypt: light microscopic study. Parasitol. Res. 110: 251-258.

Eraslan G., Çam Y., Eren M., Liman B.C. 2004: Changes in malondialdehyde level and catalase activity and effect of toltrazuril on these parameters in chicks infected with Eimeria tenella. Bull. Vet. Inst. Pulawy 48: 251-255.

Fisch S., Gray S., Heyman S., Haldar S.M., Wang B., Pfister O., Cui L., Kumar A., Lin Z., Sen-Banerjee S., Das H., Peterson C.A., Mende U., Burleigh B.A., Zhu Y., Pinto Y., LiAO R., JAIN M.K. 2007: Kruppel-like factor 15 is a regulator of cardiomyocyte hypertrophy. Proc. Natl. Acad. Sci. USA 104: 7074-7079.

Green D.R. 2000: Apoptotic pathways: paper wraps stone blunts scissors. Cell 102: 1-4.

Georgieva N.V., Koinarski V., Gadjeva V. 2006: Antioxidant status during the course of Eimeria tenella infection in broiler chickens. Vet. J. 172: 488-492.

Hishikawa K., Oemar B.S., Tanner F.C., Nakaki T., Lüscher T.F., FujII T. 1999: Connective tissue growth factor induces apoptosis in human breast cancer cell line MCF-7. J. Biol. Chem. 274: 37461-37466.

Hong Y.H., Lillehoj H.S., Lee S.H., Dalloul R.A., LillehoJ E.P. 2006: Analysis of chicken cytokine and chemokine gene expression following Eimeria acervulina and Eimeria tenella infections. Vet. Immunol. Immunopathol. 114: 209-223.

Kaiser P., Rothwell L., Galyov E.E., Barrow P.A., BurnSide J., Wigley P. 2000: Differential cytokine expression in avian cells in response to invasion by Salmonella typhimurium, Salmonella enteritidis and Salmonella gallinarum. Microbiology 12: 3217-3226.

Kang K.W., Wagley Y., Kim H.W., Pokharel Y.R., Chung Y.Y., Chang I.Y., Kim J.J., Moon J.S., Kim Y.K., Nah S.Y., KANG H.S., Он J.W. 2007: Novel role of IL-6/SIL-6R signaling in the expression of inducible nitric oxide synthase (iNOS) in murine B16, metastatic melanoma clone F10.9, cells. Free Radic. Biol. Med. 42: 215-227.

Kvičerová J., Pakandl M., Hypša V. 2008: Phylogenetic relationships among Eimeria spp. (Apicomplexa, Eimeriidae) infecting rabbits: evolutionary significance of biological and morphological features. Parasitology 135: 443-452.

Li M., OoI H. 2009: Fecal occult blood manifestation of intestinal Eimeria spp. infection in rabbit. Vet. Parasitol. 161: 327-329.

Liu J., Deng M., Lancto C.A., Abrahamsen M.S., RutherFORD M.S., ENOMOTO S. 2009: Biphasic modulation of apoptot- ic pathways in Cryptosporidium parvum infected human intestinal epithelial cells. Infect. Immun. 77: 837-849.

Livak K.J., Schmittgen T.D. 2001: Analysis of relative gene expression data using real-time quantitative PCR and the 2(-Delta Delta C(T)) method. Methods 25: 402-408.

Lüder C.K., Stanway R.R., Chaussepied M., Langsley G., Heussler V.T. 2009: Intracellular survival of apicomplexan parasites and host cell modification. Int. J. Parasitol. 39: 163-173.

Lüder C.K., Walter W., Beuerle B., Maeurer M.J., Gross U. 2001: Toxoplasma gondii down-regulates MHC class II gene expression and antigen presentation by murine macrophages via interference with nuclear translocation of STATlalpha. Eur. J. Immunol. 31: 1475-1484.

Lynagh G.R., Bailey M., Kaiser P. 2000: Interleukin-6 is produced during both murine and avian Eimeria infections. Vet. Immunol. Immunopathol. 76: 89-102.

Maalouf S.W., Talhouk R.S., Schanbacher F.L. 2010: Inflammatory responses in epithelia: endotoxin-induced IL-6 secretion and iNOS/NO production are differentially regulated in mouse mammary epithelial cells. J. Inflamm. 7: 58.

MacMicking J., Xie Q.W., Nathan C. 1997: Nitric oxide and macrophage function. Annu. Rev. Immunol. 15: 323-350.

Major P., Tóth S., Goldová M., Révajová V., KožÁrová I., Levkut M., Mojžišová J., Hisira V., Mihok T. 2011: Dynamic of apoptosis of cells in duodenal villi infected with Eimeria acervulina in broiler chickens. Biologia 66: 696-700.

Marnell L., Mold C., Du Clos T.W. 2005: C-reactive protein: ligands, receptors and role in inflammation. Clin. Immunol. 117: 104-111.

Metwaly M.S., Dkhil M.A., Al-Quraishy S. 2014: Anti-coccidial and anti-apoptotic activities of palm pollen grains on Eimeria papillata-induced infection in mice. Biologia 69: 254-259.

Metwaly M.S., Dkhil M.A., Gewik M.M., Al-Ghamdy A.O., Al-Quraishy S. 2013: Induced metabolic disturbance and growth depression in rabbits infected with Eimeria coecicola. Parasitol. Res. 112: 3109-3114.

Montgomery H.A.C., Dymock J.E. 1961. The determination of nitrite in water. Analyst 86: 414-416.

OhкaWa H., Оhishi N., Yagi K. 1979: Assay for lipid peroxides in animal tissues by thiobarbituric acid reaction. Anal. Biochem. 95: 351-358.

Oncel T., Gulegen E., Senlik B., Bakirci S. 2011: Intestinal coccidiosis in angora rabbits (Oryctolagus cuniculus) caused by Eimeria intestinalis, Eimeria perforans and Eimeria coecicola. Yüzüncü Y11 Üniversitesi Vet. Fak. Derg. 22: 27-29.

PaKandl M. 2009: Coccidia of rabbit: a review. Folia Parasitol. 56: $153-166$.

Pakandl M., Hlásková L., Poplštein M., Chromá V., Vodička T., Salát J., Mucksová J. 2008: Dependence of the immune response to coccidiosis on the age of rabbit suckling. Parasitol. Res. 103: 1265-1271.

Pakandl M., Sewald B., Drouet-Viard F. 2006: Invasion of the intestinal tract by sporozoites of Eimeria coecicola and Eimeria intestinalis in naive and immune rabbits. Parasitol. Res. 98: 310-316.

Rasul A., Ding C., Li X., Khan M., Yi F., Ali M., Ma T. 2012: Dracorhodin perchlorate inhibits PI3K/Akt and NF- $\kappa$ B activation, up-regulates the expression of $\mathrm{p} 53$, and enhances apoptosis. Apoptosis 17: 1104-1119.

Renaux S., Quéré P., Buzoni-Gatel D., Sewald B., Le Vern Y., Coudert P., Drouet-Viard F. 2003: Dynamics and responsiveness of T-lymphocytes in secondary lymphoid organs of rabbits developing immunity to Eimeria intestinalis. Vet. Parasitol. 110: 181-195.

Salminen A., Hyttinen J.M., Kauppinen A., Kaarniranta K. 2012: Context-dependent regulation of autophagy by IKKNF- $\kappa$ B signaling: impact on the aging process. Int. J. Cell. Biol. 2012: $1-15$. 
Schito M.L., Barta J.R., СновотAR B. 1996: Comparison of four murine Eimeria species in immunocompetent and immunodeficient mice. J. Parasitol. 82: 255-262.

Swaggerty C.L., Kogut M.H., Ferro P.J., Rothwell L., PeVZNER I.Y., KAISER P. 2004: Differential cytokine mRNA expression in heterophils isolated from Salmonella-resistant and -susceptible chickens. Immunology 113: 139-148.

Taubert A., Behrendt J.H., Sühwold A., Zahner H., HerMosilla C. 2009: Monocyte- and macrophage-mediated immune reactions against Eimeria bovis. Vet. Parasitol. 164: 141153.
Vadlejch J., Knízková I., Makovcová K., Kunc P., Jankovská I., Janda K., Borkovcová M., LAngrová I. 2010: Thermal profile of rabbits infected with Eimeria intestinalis. Vet. Parasitol. 171: 343-345.

Yan Z., Ming-Xue Z., Zhi-Yong X., Huan-Cheng X., XiaOZhen C., Sha-Sha Y., Wen-Long Z., Shan L., Qiang-Hua L., Rui B. 2015: Relationship between Eimeria tenella development and host cell apoptosis in chickens. Poult. Sci. 94: 2970 2979

Cite this article as: Abdel-Haleem H.M., Aboelhadid S.M., Sakran T., El-Shahawy G., El-Fayoumi H., Al-Quraishy S., Abdel-Baki A.-A.S. 2017: Gene expression, oxidative stress and apoptotic changes in rabbit ileum experimentally infected with Eimeria intestinalis. Folia Parasitol. 64: 012. 